\title{
The Church and New Media Technology: Communicating and Sharing Faith through the WhatsApp Media Platform
}

\section{Josephat Mutangadura ORCID iD: https://orcid.org/0000-0003-4197-1041}

\section{Itai Offat Manyanhaire}

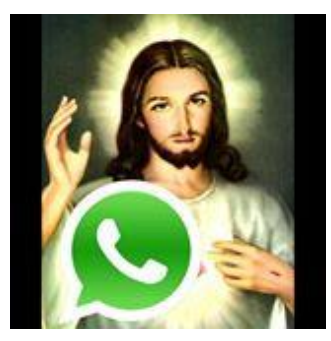

\section{Abstract}

The Church finds herself in the midst of a technological revolution, the biggest communication shift since the advent of the printing press, leaving it at a crossroad. The need for believers to use new media outlets for communication is increasingly becoming a reality because church members are ever embracing new media outlets in other spheres of their lives and moving away from traditional forms of media. This transition is filtering phenomenally into the church and the religious life of its members. The intention of this research was not only to reveal how the believers could exist in the digital era, but to also show how they could proclaim the gospel today effectively, exploiting all that the new age has to offer. Particular attention was given to the generation, content and target audiences of Christian WhatsApp 'chat' messages. Of note was the net effect of such messages on the wider consumers whilst at the same time raising concern over the issues of security and privacy as enshrined in the use (or abuse) of WhatsApp on mobile and other computer gadgets. The 
WhatsApp platform was selected for study because of its prevalence and accessibility among the majority of members in the Zimbabwean congregations. The paper therefore extracted WhatsApp chat messages that were faith related and analysed them in the light of new media technology and the spread of the Christian faith. Messages received and forwarded through the WhatsApp platform were reproduced as evidence of new media utilization in evangelizing and Christian community building. If the church's missions of evangelization, formation, community-building, and social relevance are to continue in future generations, church members must harness these tools and utilize them now.

Keywords: chat, smartphone, digital era, WhatsApp messenger

\section{Introduction}

The Church finds herself in the midst of a technological revolution, the biggest communication shift since the advent of the printing press, leaving it at a crossroad. The need for believers to use new media outlets for communication is increasingly becoming a reality, because church members are ever embracing new media outlets in other spheres of their lives and moving away from traditional forms of media. This transition is filtering phenomenally into the church and the religious life of its members. How do churches remain relevant to their constituents in an age where the communications landscape is now characterized by connectivity, mobility, and immediacy? How do they preserve the core values of the church and keep her integrity intact when daily communication increasingly takes place in a disruptive and distracting bazaar of digital sounds and sights? (Baron 2010). How can they avoid becoming marginalized and lose credibility in a world which now straddles both geographic and digital spaces? Such are the emerging questions and challenges encountered by the church situated in the digital communications era. The study is therefore starting off from this position as it seeks to uncover the net benefit of using the WhatsApp messaging platform as one of the digital age technologies the church has had to face and make use of.

\section{Methodology}

The research undertook to analyse the WhatsApp messaging facility on An- 
droid smartphones as an evangelisation tool. The WhatsApp platform was selected for study because of its prevalence and accessibility among the majority of members within the Zimbabwean Christian congregations. A WhatsApp account was therefore opened using the Bluestacks application and installed on the laptop of the researchers. It was installed on the laptop so that it would be easy to reproduce chat pages in the study without having to download them from the mobile handset, which would compromise the picture appearance and readability. Links were purposively sought with wider Christian friends and groups so that the account would engage in participant observation of the facility use. Ten WhatsApp extracts were therefore picked and have been reproduced in this paper for use in the study under various subtopics as set out in the research agenda. The study therefore extracted WhatsApp chat messages that were faith related and analysed them in the light of new media technology and the spread of the Christian faith. Messages received and forwarded through the WhatsApp platform were reproduced as evidence of new media utilization in evangelizing and Christian community building. This was done with a view to show the positioning of the church in the digital age as both a survival and exploitative strategy to maximize its outreach and influence.

\section{Theoretical Framework}

A growing development of $21^{\text {st }}$-century life is that mobile communication devices have become inseparable companions and indispensable personal valets. If one needs to understand the impact of WhatsApp on the digital generation it is vital to look at how media can influence human life and their activities. Media effects represent one of the core ideas of communication research from the beginning. Elihu Katz (2001: 472) characteristically posits that all communication research 'is about effect'. In this study two media effects theories are used as framework for understanding the effect of WhatsApp as a media platform, namely the Media Dependency Theory and Hypodermic Needle Theory (or magic bullet theory).

The hypodermic needle theory is a model of communications, also referred to as the 'magic bullet', or the 'profound effects' theory. Essentially this model holds that an intended message is received directly and wholly accepted by the receiver. The phrasing 'hypodermic needle' is meant to give a mental image of a message's direct infusion into an individual. The 'hypoder- 
mic needle theory' implies that mass media have a direct, immediate and powerful effect on its audiences. The mass media in the 1940s and 1950s were perceived as a powerful influence on behavioural change. The hypodermic theory by Harold Lasswell (1979) suggests that the mass media could influence a very large group of people directly and uniformly by 'shooting' or 'injecting' them with appropriate messages designed to trigger a desired response. The 'magic bullet' theory graphically assumes that the media's message is a bullet fired from the 'media gun' into the viewer's 'head' (Berger 1995). Several factors contributed to this 'strong effects' theory of communication, including the fast rise and popularization of radio and television which, for example, led to the emergence of the persuasion industries, such as advertising and propaganda. The hypodermic theory expresses the view that the media are a dangerous means of communicating an idea because the receiver or audience is powerless to resist the impact of the message. There is no escape from the effect of the message in these models. The population is seen as a sitting duck. Media dependency theory is also significant in this study, as WhatsApp users are seen to depend so much on this application for most of their communication. WhatsApp users spend much of their time on the application, resulting in them depending on it for much of what they learn and believe in each day. The degree of dependence, according to the media dependency theory, can be directly proportional to individuals as the media have the ability to satisfy the audience needs. An individual will become more dependent on media if the medium satisfies their needs. WhatsApp users tend to have their needs satisfied by the application as they chat with others; the way WhatsApp users constantly check messages, anticipate messages, check who is online and get affected when there is no response from other users is clear evidence that WhatsApp satisfies their needs and hence the degree of dependence is heightened.

\section{Review of Related Literature Overview of WhatsApp and its Main Features}

WhatsApp Messenger is a proprietary, cross-platform instant messaging subscription service for smartphones and selected feature phones that uses the internet for communication. In addition to text messaging, users can send each other images, video and audio media messages as well as their location using 
integrated mapping features. One major driver for WhatsApp to function successfully for communication is that one has to persuade their most frequent texting peers to download and install the application too.

WhatsApp Inc. was founded in 2009 by US citizens Brian Acton and Jan Koum (also the CEO), who are both former employees of Yahoo!, and is based in Mountain View, California (Jackson 2012). The company employs 55 people (Albergotti, MacMillan \& Evelyn 2014). The company is currently in the process of takeover after Facebook Inc. announced its acquisition of WhatsApp Inc. for US\$19 billion on 19 February 2014 (Albergotti et al. 2014). In a December 2013 blog post, WhatsApp claimed that 400 million active users use the service each month (Koum 2014). As of 22 April 2014, WhatsApp had over 500 million monthly active users, 700 million photos and 100 million videos being shared each day, and the messaging system handles more than 10 billion messages each day (Chowdhry 2014). If WhatsApp had been a country, it would have been the third-largest in the world after China and India.

As part of its features, WhatsApp Messenger shows one's chats in little text bubbles, gives a time stamp for messages, notifies when a text has been viewed by a recipient, and lets users include photos, audio notes, and videos as part of their conversations. With Whats App Messenger you can also change your background and send a GPS location to an interactive map. Pre-made status statements such as 'I'm busy', 'WhatsApp only' or even 'My battery is about to die', are used as users' status.

The status can be personalized with Christian believers making evangelical wonders in this section. Examples that have been picked include 'Zvikasashamisa haasi mwari', 'NaJesu Tinovimba', among others. In the extract below, check the status 'faith accepts, believes, endorses and confesses God's Word' (Gal. 3: 6; Rom. 10: 8). The page even indicates the dates such that statuses can be changed according to the season in the interest of the account holder or religious festivals at hand. Check the status of the two figures below. Faith accepts, endorses and confesses God's Word' (Gal. 3: 6; Rom. 10: 8), 'Commit your way to the Lord, trust in him and He will act'. These two statements are in themselves statements of faith.

They inspire the account holder and any other of the group or contact list member. The evangelization becomes ripple factor within the group or contact list. 
The Church and New Media Technology

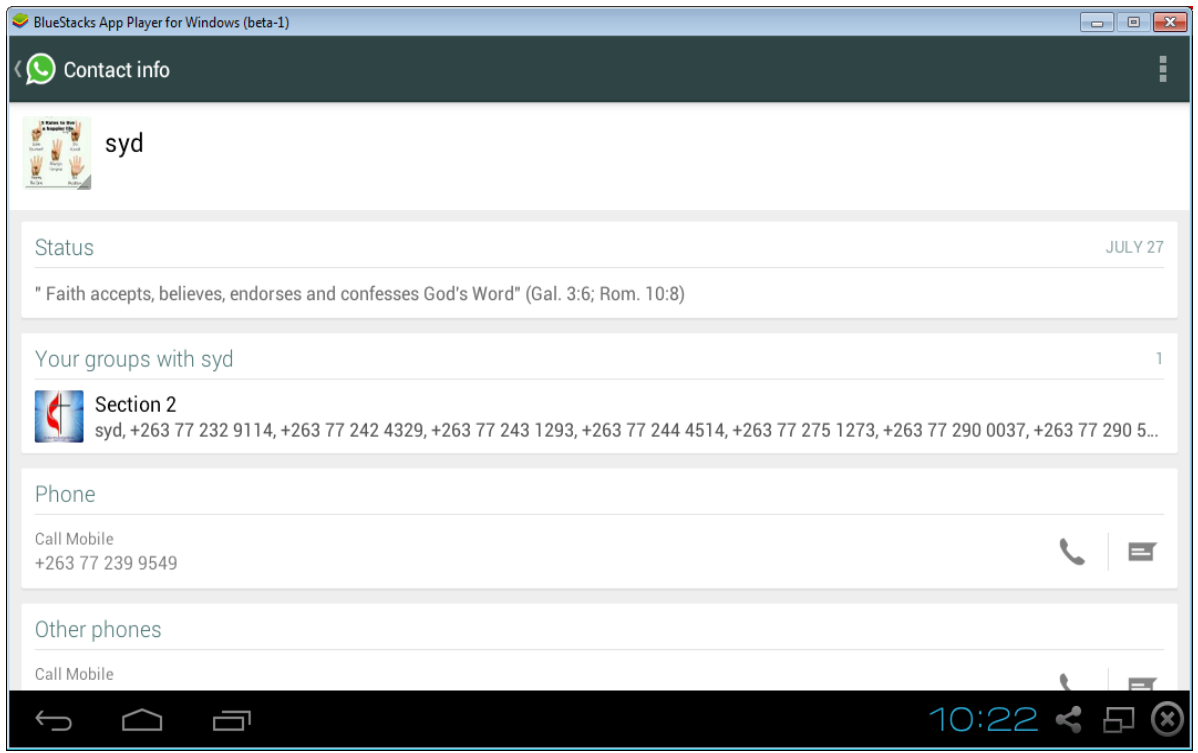

\section{Figure 1: WhatsApp extract with biblical citations}

Status

Commit your way to the Lord; trust in him and he will act

Phone

Call Mobile

+263773832356

Figure 2: WhatsApp extract with Biblical citation 
It is possible to block specific contacts from within the app for whatever reason if one feels like stopping the incoming chats from that direction. These are some of the nice extra features on this application.

One thing WhatsApp does exceptionally well is group messages. Users can use the Broadcast Message feature to bring up their entire list of contacts then click radio buttons to quickly add contacts for a message blast. There's also a new group feature, which lets one add contacts for a group message. The study is interested in both group and peer utilization of the WhatsApp messaging for the purposes of faith distribution. Users have the ability to also look back over the group messages and list just the locations or just the media added to the group chat by all members. These are not amazing or groundbreaking features, but they are a bit more than what one can get with the standard messaging features on most phones.

Saving money is one biggest advantage of using WhatsApp, even when communicating internationally. In other words, with WhatsApp Messenger, and a little cooperation from the most-texted friends and family, one could easily get the lowest-cost texting plan and save some money every month on their smartphone bill. This ideally fits in well with evangelical messages that do come in tonnes at next to nothing in terms of costs. The gospel would not spread without restrictive costs.

Overall, WhatsApp Messenger is not much different from the textmessaging services one gets on one's smartphone; however, WhatsApp offers a few neat extras that make it a little more fun and useful. This is the other reason why it works well in Christian evangelism as composers can utilize all sorts of additives to make it more appealing. If one does a lot of texting, this application is a must-have, giving users unlimited free texts with all their peers without having to worry about extra charges, even internationally.

\section{The Church and New Media Technology}

The mandate of Christ is clear and unambiguous: proclaim the Gospel to the nations and invite everyone to share Christ's life in his Church. Contemporary media technologies offer not only priests, but all the faithful, a means to fulfil this mandate in an unprecedented way (Baron 2010).

As churches and believers alike consider new opportunities introduced by new communications technologies and environments like WhatsApp and others, it is worth remembering that one of the key defining features of 
humanity is the ability to communicate. All aspects of human activity, including the accomplishment of the principal tasks of the church, involve a communicative dimension. Consequently, whether proclamation (kerygma), community (koinonia), services (diakonia), advocacy (propheteia), or worship (leitourgia) (Pazmiño 2008: 46-55), all these tasks involve communication acts and events that are integrally linked to communications media and technologies. It is also worth remembering that many of the high points in the life of God's people were intricately linked to historical developments in human communications.

Encoding the spoken Word in written form helped to preserve both Testaments over the ages. Having koine Greek as a common lingua franca enabled the spread of early Christianity across a much larger ethnic and geographic extent than would otherwise have been possible. Circulating written gospels and dictated epistles proved instrumental to the evangelism and discipleship efforts of the apostles. Mechanically inking pages using movable types put the Word of God into the hands of the literate masses. Transmitting radio waves across political borders birthed and nurtured churches under conditions of oppression and persecution. These examples from history serve to illustrate the very intimate, though sometimes overlooked relationship between developments in communications history and the life of the church.

The revelations above are reminders that encourage us to take note of the fact that the church can make a difference at a time of rapid global adoption of digital communications technologies and increased communication within digital spaces.

\section{Absence of Clear Laws Governing Mobile Licensing and Usage of the WhatsApp Media Messaging Platform \\ Security}

How secure are WhatsApp accounts? In May 2011, a security hole was reported which left WhatsApp user accounts open for session hijacking and packet analysis (McCarty 2011). WhatsApp communications were not encrypted, and data were sent and received in plain text, meaning that messages could easily be read if packet traces were available (Brookehoven 2011). That means it is possible that WhatsApp can leak username, mobile numbers and messages. In September 2011, WhatsApp released a new version of the Messenger application for iPhones, closing critical security holes that allowed 
forged messages to be sent and messages from any WhatsApp user to be read (Kurtz 2011).

On 6 January 2012, an unknown hacker published a website (Malekhosseini 2018) that made it possible to change the status of an arbitrary WhatsApp user, as long as the phone number was known. To make it work, it only required a restart of the app. According to the hacker, it is only one of the many security problems in WhatsApp. On 9 January 2012, WhatsApp reported that it had resolved the problem, although the only measure actually taken was to block the website's IP address. Does this pose any challenge to the spread of faith-related messages? I suppose not. The word of Jesus Christ needs no privacy nor security as it is secure by itself. Satanists as a new phenomenon against the spread of the word would spread counter messages as seen in the chat below but to no avail in this crusade.

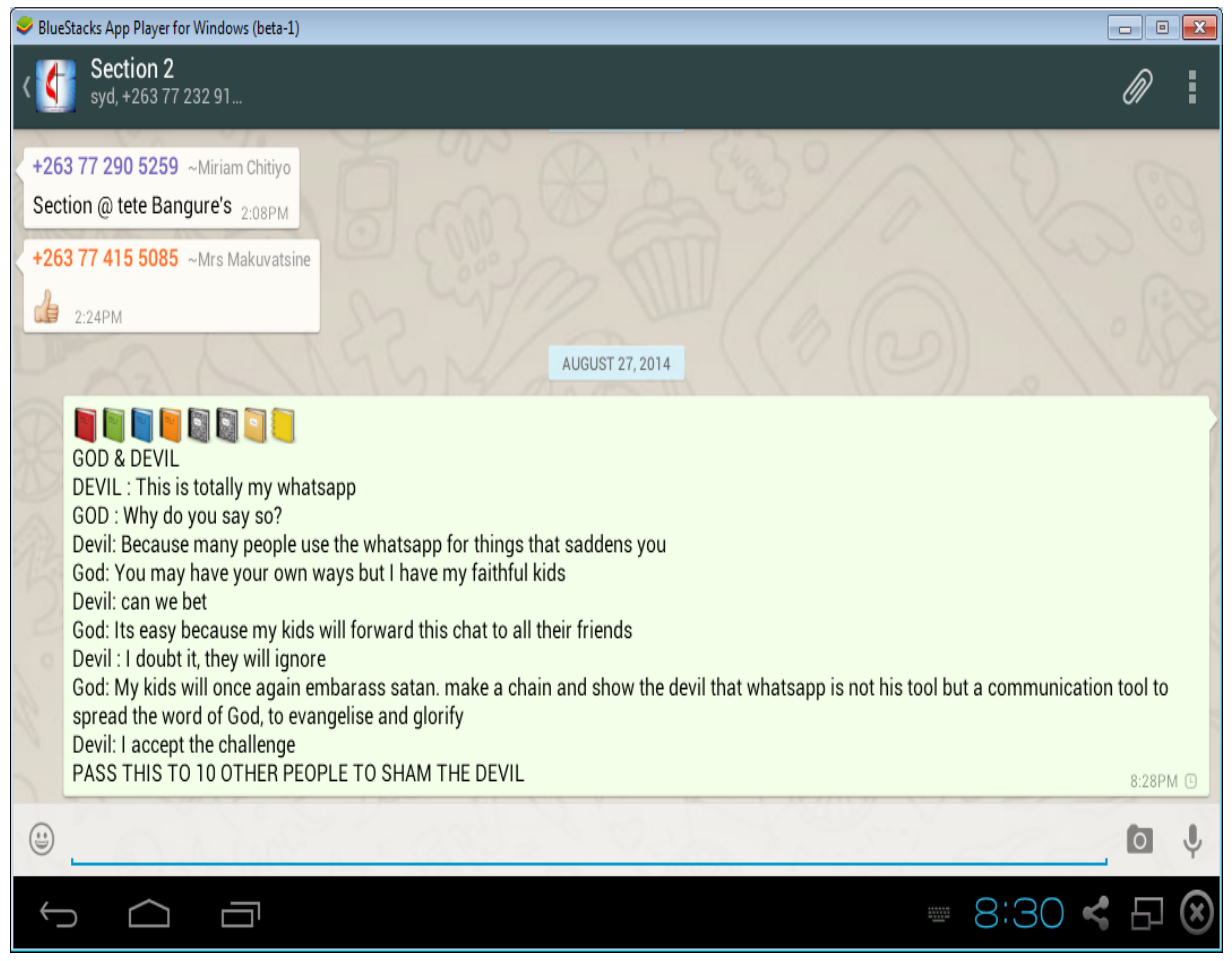

Figure 3: WhatsApp extract showing social media threats 


\section{Privacy}

On top of being a fully registered mobile phone user, WhatsApp demands that you upload your number prefixed with your country code. What that means is the user is now identifiable through their mobile number and network as well as by their country. A major privacy and security problem has been the subject of a joint Canadian-Dutch government investigation. The primary concern was that WhatsApp required users to upload their mobile phone's entire address book to WhatsApp servers so that WhatsApp could discover who, among the users' contacts, is available via WhatsApp. While this is a fast and convenient way to quickly find and connect the user with contacts who are also using WhatsApp, it means that their address book was then mirrored on the WhatsApp servers, including contact information for contacts who are not using WhatsApp. This information was stored in hashed, though not salted form and without 'additional' identifying information such as a name, although the stored identifying information is sufficient to identify every contact (Privacy Commissioner of Canada 2013). On 31 March 2013, the Saudi Arabia telecommunications authority, the Communications and Information Technology Commission (CITC), made a statement regarding possible measures against WhatsApp, among other apps, that the service providers needed to take steps to comply with monitoring and privacy regulations (Quadri \& Khan 2019).

According to features of WhatsApp, a user does not need to send a friend request to send messages to another user. However, users can block numbers on WhatsApp but they still show their presence to the blocked peer. As a result, a public corporation of the state of Schleswig-Holstein has advised against using WhatsApp, as the service lacks privacy protection such as endto-end client-side encryption technology.

\section{WhatsApp and the Gospel Evangelical Super Highway}

\section{THE GREAT COMISSION [Matthew 28: 18-20]}

18 Then Jesus came to them and said, 'All authority in heaven and on earth has been given to me. 19 Therefore go and make disciples of all nations, baptizing them in the name of the Father and of the Son and of the Holy Spirit, 20 and teaching them to obey everything I have commanded you. And surely, I am with you always, to the very end of the age'. 
The history of human communication is marked by significant turning points which have reconfigured the way people think, order their lives, and relate to one another. Whether as a result of the invention of computers, or the Internet, these communication technologies have introduced deep and irrevocable societal level changes over the course of human history. Digital spaces are presently undeniable extensions of human sense of place and are significant habitats in today's expanded global communications ecosystem. Although only in its early years, the innovations of the present digital age have already transformed the speed, scope, and scale of everyday human communications. All this has left a profound impact on contemporary life, with new conditions and common spaces introduced that are consciously as well as unconsciously shaping communications habits, behaviours and lifestyles. These characteristics of hyperconnectivity have thus dramatically reshaped the landscape of politics, economics, media, arts and entertainment, religion, law, and education, and have reordered work, social, family, and personal life. Indeed, this form of radical, non-hierarchical connectivity has now become a given in mainstream culture. With these shifts, the benefits of hyperconnectivity offer new opportunities to be harnessed and profited from.

The challenge to participate in building this new world at the digital frontier calls for a radical rethink of the how, where, who, and with what of Christian ministry. Effective participative presence in this new world will require those in traditional ministry roles to recognize the wide range of new communications genres, move out of their comfort zones, and interact regularly on popular communications platforms.

In terms of scope and reach, however, the vision of participative presence can only be advanced through the active involvement of the net generation believers in whom reside native intuitions in digital environments, expert knowhow, and the ability to exploit the affordances of digital technologies for Kingdom purposes.

\section{Discussion of Findings}

\section{Who are the Originators of WhatsApp Faith-related Chats?}

It was established that individuals subscribe to the WhatsApp service as individuals, but can form groups later. The originators of faith-related messages on WhatsApp are the individuals who then feed into the channel of others. An individual believer will have an inspiration to pick and share in the 
same way they have been sharing the word in sermons and prayers daily and traditionally. Initially one would expect Christian leaders to be fronting the composition of faith-related chats. It should not be surprising, however, to note that the messages are emerging from all angles.

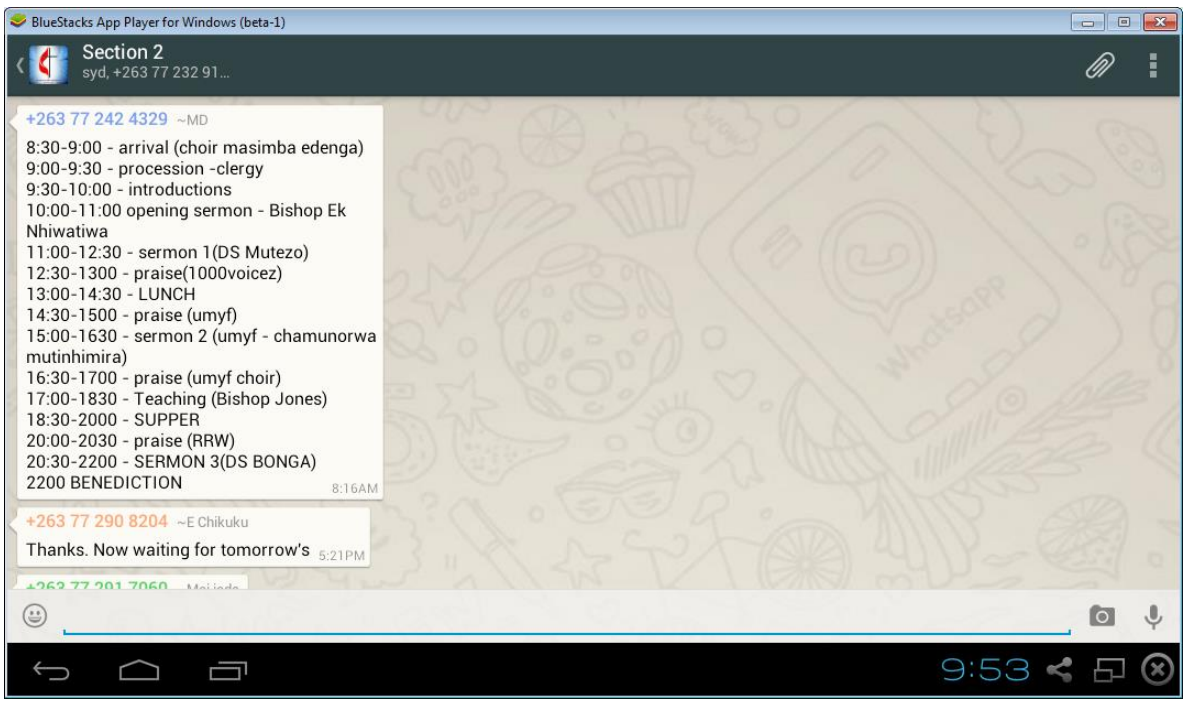

\section{Extract 4: Section 2 Chat group}

The extract above is a single chat by a member of the group 'Section 2' of the United Methodist Church, Cold Comfort Circuit. The individual with the name and number captured had something to share, in this case, programme of events for the 'Ebenezer' event which was held at the national sports stadium. This chat is being fed into a group and all members in the group can then view and comment on the posting.

\section{Who are the Distributors, and Beneficiaries/Intended Audiences?}

The distributors of faith-related Christian messages on Whats App are neither restricted nor prescribed in any way. The originators extend from individuals who are preachers, evangelists, pastors to organizations like churches and their 
subsidiary organs. In like manner, the same are the distributors of that form of communication to beneficiaries. In the extract below, the formation of a group is indicated with all the numbers shown being those of group members. The administrator is the one who has the power to name the group as well as to recruit members. Besides the administrator, members can opt out of the group if they no longer want to continue membership. Once one is a member of a group, one can then originate and distribute messages in line with the founding purpose of the group.

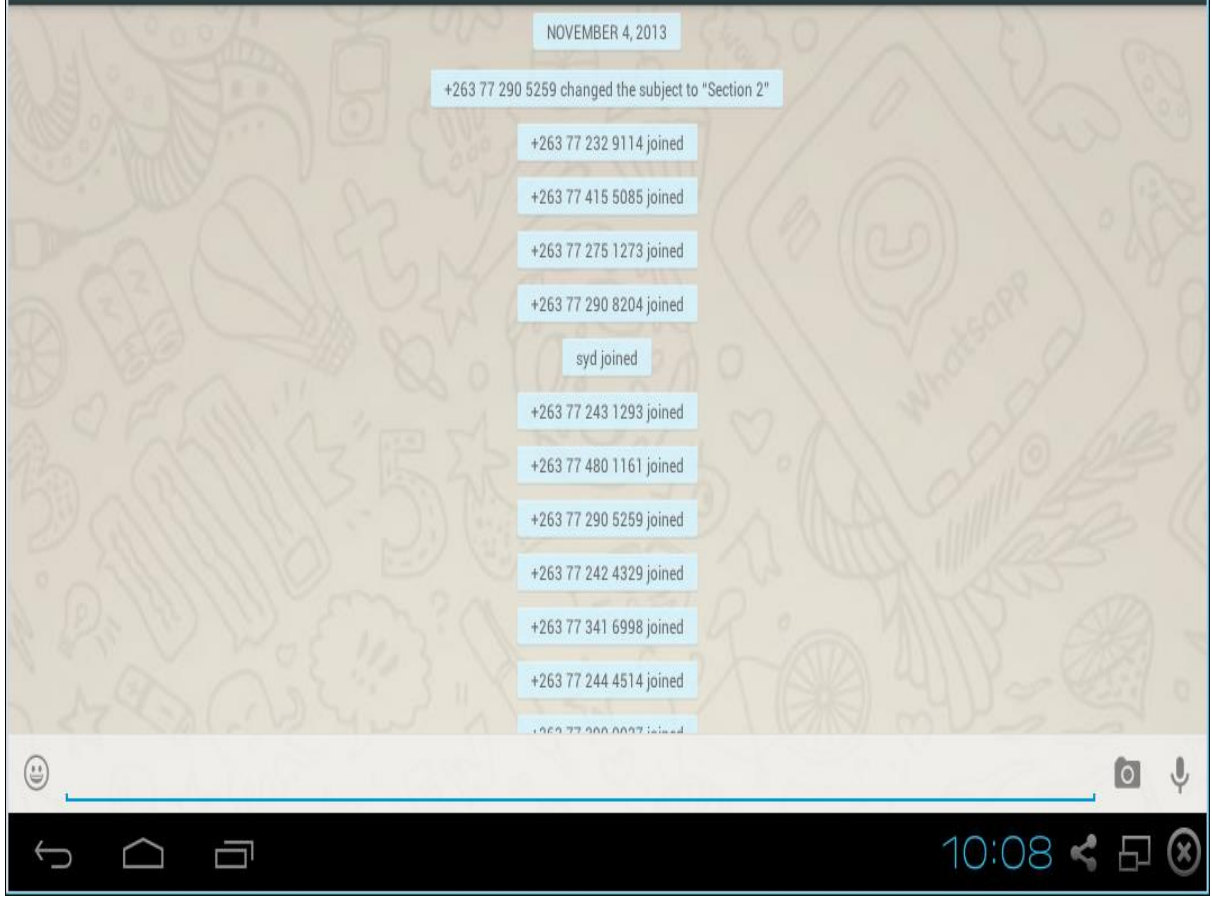

Figure 4: WhatsApp page showing how members are enrolled into a group

The audience of these WhatsApp faith-related messages are varied. In the case of individuals exchanging chain messages, the target audience are determined 
by the sender. In the case of groups, it then extends to all those registered in the group. For me to benefit from messages passing through 'Section 2' of the Cold Comfort United Methodist Church, I must ask the administrator of the group to include my number. Then only will I be able to interact with the messages and group members.

\section{Figure 5: WhatsApp extract showing Christian status}

The status of the WhatsApp subscriber is the Christian message in itself. The image in the status above represents common pictures associated with Jesus Christ. The posture displayed reveals the desire of every Christian believer to have Jesus offering them a hand to stand upon. The status message 'Back to Sender' was a popular expression after one gospel musician composed a song that appeared to suggest any bad spells cast by enemies should be sent back to the sender in the name of Jesus.

The extract below has chats and live images of believers in symbolic 
state. The choral 'Amen' and the woman dressed in church attire are all inspireing for Christians. Congratulatory and motivational statements are seen in the use of 'celebrate Harvest, and Ebenezer' themselves, important terms in the United Methodist calendar and vocabulary.

+263772900037 Peewa Dee

Amen; thank you 5:09am

\section{+26377292 4950 Livingstone Chikuku}

God bless you as you celebrate Harvest. We are together in it. Ebenezer.

Amen. Ichokwadi. 7:46AM
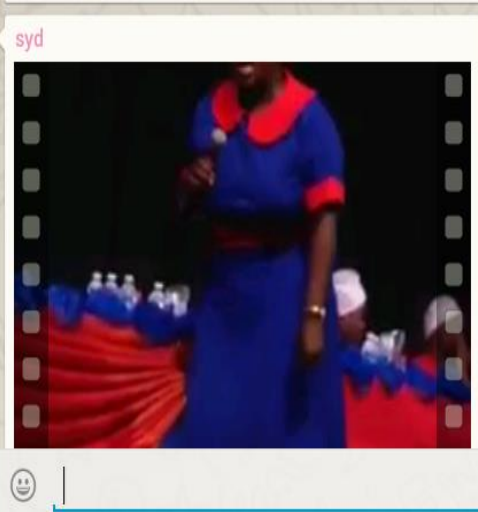

\section{Figure 6: WhatsApp page showing faith chats and images}

\section{Composition and Content of Message}

The messages carry all forms of faith expression, from direct biblical quotations to sermon like expressions with Christian meaning. The WhatsApp technology is not just a novelty or idiosyncratic, but integral to an emerging global culture that offers not just an effective means of communication, but the possibility of new Christian communities being formed that can transcend the limits imposed by geography and denominational borders. Because of these new technologies, the Church is now able to share the Gospel with many who 
would never enter the doors of religious institutions or who might never meet a preacher or pastor face to face. The content type of messages range from plain text to pictures, to audio and video messages.

The study has managed to reproduce some of the texts and images but could not do the same with audio-visuals. Audio visuals can form another study and its novel impact on modern-day faith messages and evangelization. In the area of media studies, this would incorporate citizen journalism where members of the congregation are able to capture and broadcast videos and images in real- time.

\begin{tabular}{|c|c|}
\hline Bluestacks App Player for Windows (beta-1) & $\square \quad 0 \quad x$ \\
\hline 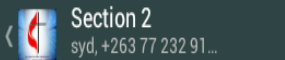 & 0 \\
\hline Thank you t:57AM & \\
\hline +26377 2329114 Ruth Musekiwa M & \\
\hline Thanks $7: 17 \mathrm{Am}$ & \\
\hline syd & \\
\hline $\begin{array}{l}\text { Gonyeti nekureba kwaro kwese kuy } \\
\text { maKeys anotokwana chete muhom } \\
\text { solution (Key) diki diki inokwana m } \\
\text { here, obviously GOD can do better } \\
\text { Nomatter how big the problem you }\end{array}$ & $\begin{array}{l}\text { d, } \\
\text { gadzira } \\
\text { ipapa } \\
\text { 7:40AM }\end{array}$ \\
\hline +26377 2924950 Livingstone Chiku & \\
\hline Amen. Ichokwadi. 8:49AM & \\
\hline$+263772424329 \sim M D$ & \\
\hline Good one, thanks. 9:51 AM & \\
\hline +26377 $2905259 \sim$ Miriam Chitiyo & \\
\hline Section@ Chitiyos Tete Bangure va & \\
\hline +263772900037 Pee wa Dee & \\
\hline (:) 1 & 04 \\
\hline$\hookleftarrow \quad \square$ & $\square$ (x) \\
\hline
\end{tabular}

\section{Figure 7: WhatsApp page showing member interaction on posting}

When a member posts something onto the group, members are persuaded to respond by way of commending or acknowledging the post. Evangelization then moves fast on high interaction among members on group chats. The con- 
cept and theory of 2 Step flow in media studies can influence reactions here.

The two-step flow of communication model hypothesizes that ideas flow from mass media to opinion leaders, and from them to a wider population. It was first introduced by sociologist Paul Lazarsfeld et al. in 1944 and elaborated by Elihu Katz and Lazarsfeld in 1955 and subsequent publications. Church leaders in the name of clergymen and lay leaders are assumed to have access to relevant religious messages and their word is authoritative. A post initiated by the pastor or any of the leadership is likely to get more reactions, thereby pushing the effect of the chat wider than when initiated by ordinary group members. Pastors and leaders have an immediate following in whatever they initiate or direct. This study will actually be extended in the next articles to focus on the effect of Twitter as a tool for evangelization. The Twitter arrangement works on followership, and the 2-step flow concept will make more sense and have more influence in spreading Christian messages.

The sermon above immediately attracted responses from members with 'ichokwadi' (that is true) and 'amen'. Something posted at 7:40 AM attracted two responses within the next hour, all acknowledging and approving.

Ndoda unzwisise zvinoreva kutanga or kupera kwemwedzi mudikanwi, its not about kubhadhara rent pamba paunoroja, its not about paying your child's fees, its not about paying your medical or funeral monthly subscription, its not about paying your utility bills, its not about getting your salary but zvinechekuita nekufamba kwemazuva nemakore ako panyika pano ,ndoda unyatsonzwisisa kuti kune vakomana nevasikana harahwa nechembere pamwe nemaLadies and Gentlemen vawakatangirana navo mwedzi waJuly muchifara mese but havana kuupedza sezvawaita iwe ,kune vawakapembera navo muchideedzera HAPPY NEW YEAR 2014 but havana kusvika pakati paro gore rino asi iwe wakasvika ,but ndoda uzive kuti inyasha dzaMwari kuti uve pauri nhasi ipapo uchiita zvauri kuita izvozvo, July aive nezvakawanda zvaaive nazvo zvaiifadza kana kusuwisa but rega ndikuudze July haaasi August. Chando chatoenda naJuly hongu but August ane mhepo dzake, kkkkkkk ndoda unyatsonzwisisa kana ndichitaura nyaya yemhepo, Mhepo chinhu chinobhowa,kushungurudza ,kutosvora ,above all mhepo inokonzera Confusion haiunzi mufaro ,Zvino ndoda ungware hama yangu nekuti August wawapinda uyu anouya netwo types of Mhepo, mhepo yekutanga ndiyo inosimudza dust neguruva ichitosvora nekusvibisa isu vemaSuit haaaa iyi mhepo yakashata but iri nani kani pane imwe yacho yandiri kuda kutaura nezvayo pano nhasi ,August in shona unonzi Nyamavhuvhu becoz mhepo dzinooneka nedzisingaoneki dzinovhuvhuta zvakanyanya mwedzi uyo ,ndiwo mwedzi unotambira hama dzedu dzakawanda kumakuva / kumarinda ,ndomwedzi unocherechedzwa vafi zvakanyanya uye vasati vaziva Jesus Christ ndomwedzi wavanoti tiri kudzora vafi mumusha / kurova makuva , zvabva zvandisvitsa pamhepo yechi2 inova mweya yetsvina ,Hapana umwe mwedzi unosimudziranwa mhepo saAugust becoz a lot of people vanenge varasa communication yavo naMwari vave kumutsana nevafi ,hapana munhu anogumbura Mwari semunhu anomutsa kana kunetsana nevakafa ,shoko robva rati vakafa havana chavachaziva and havachina mugove pano panyika iwe takarisima kuenda kumukuva hanzi mukai muchengete / mutarise vana kkkkkk hama yangu ziva zvaunofambira August uno ,ziva chaunoshandisira mari yako mwedzi uno ,cherechedza ungano dzauri kuda kuenda mwedzi uno ,ndinoda urangarire August ane record hombe yemaAcciddents, ropa rakawanda rinodeuka in August becoz a lot of people wil pleasing and worshiping the devil and the dead not the Living God ,zvino hasha dzaMwari dzinnnvanva kana ikarımhidza vakafa kudarika musiki Mutendi shinna kunamata iwe ndati Aurust ane mhenn this is the month inntennwa 
Elaborate sermons and any other message compositions are shared throughout the group chats. Above is a group formed as a family chat group. A lengthy message is exchanged in the local Shona language that all the members share. The impact of language is also crucial and would require a separate investigation into the use of new media technology in evangelization.

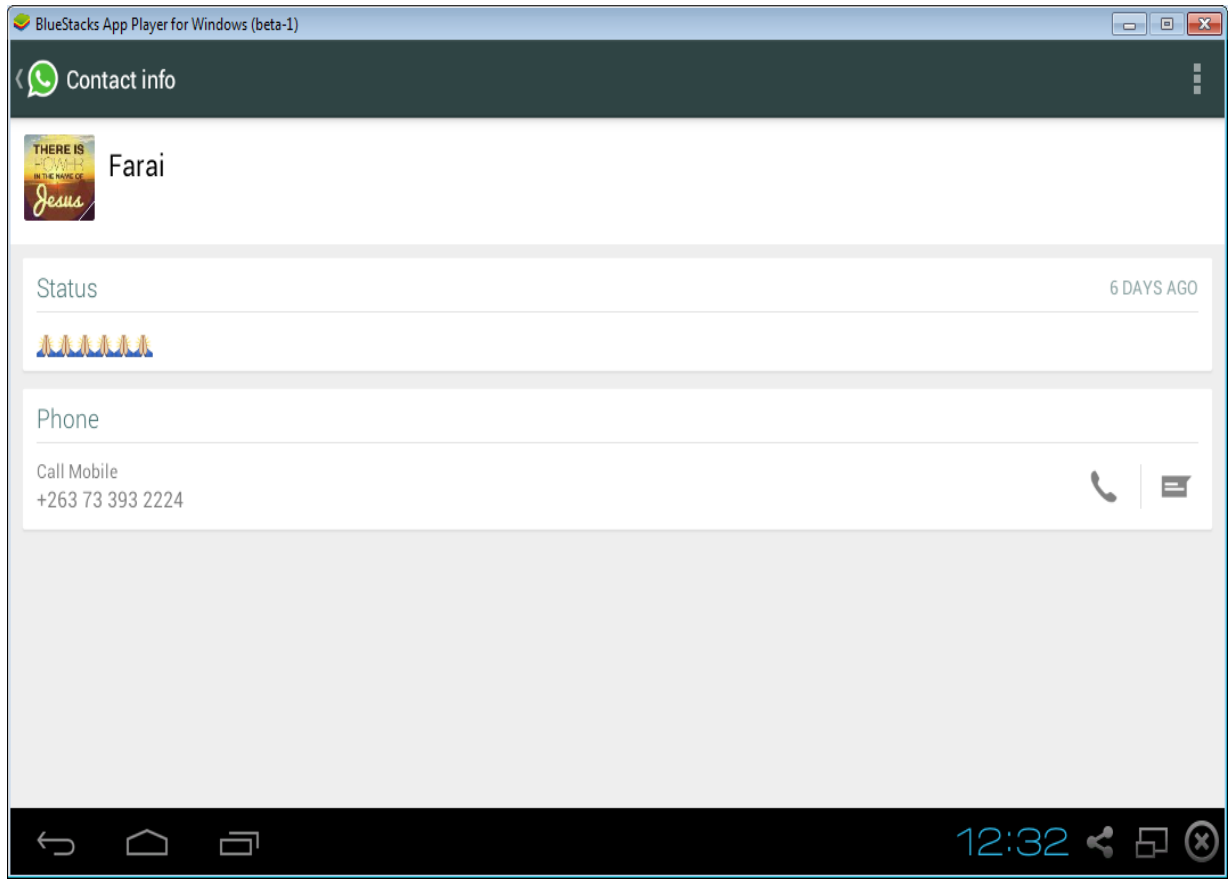

\section{Figure 9: WhatsApp visual faith messages}

The extract above utilizes visual evangelization in its outlook. The WhatsApp facility allows for subscribers to import and install their personalized images or to make use of pre-installed emojis. The praying hands can be used to make all relevant kind of impressions on those sharing the group chat. The one below captures the subscriber's personal perception of living a religious life. 'Nguva haisi yedu', the Christians are always reminded that God's time will control and determine everything. A true believer will always pay reverence to his/her God since anytime one can die and be called to account before the Lord. 


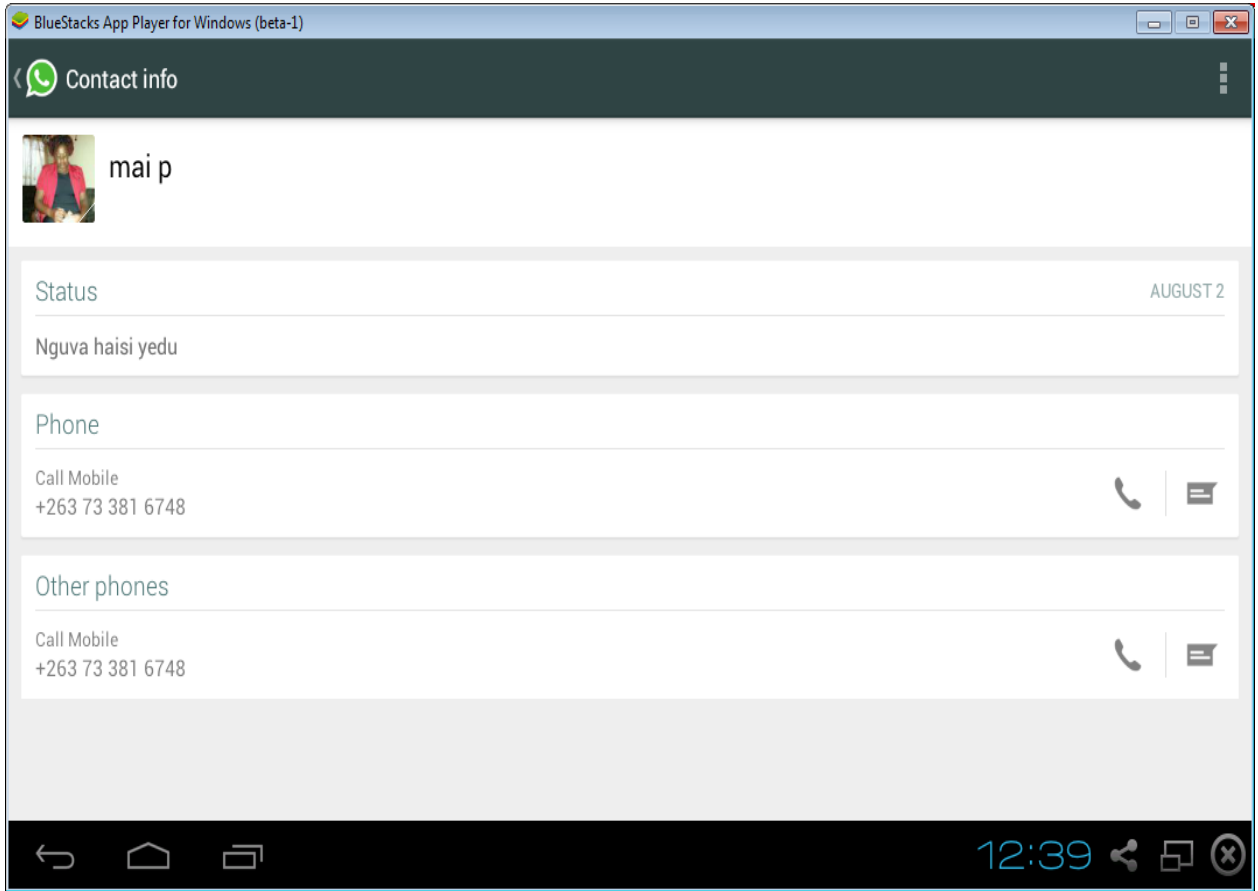

\section{Figure 10: WhatsApp faith status}

\section{The Blind Side of New Communication and Media Technologies}

One of the important theses forwarded by Marshall McLuhan a media guru is that media technologies are both extensions of human abilities as well as amputations of human capacities (McLuhan 1965). Gordon illustrates and explains McLuhan's thesis of extensions and amputations in this way:

Whether you are pedaling a bicycle or speeding down the freeway in your car, your foot is performing such a specialized task that you cannot, at that moment, allow it to perform its basic function of walking. So, although the medium has given you the power to move much more quickly, you are immobilized, paralyzed. In this way, our technologies both extend and amputate. Amplification becomes amputation (Gordon 2010: 109). 
McLuhan's thesis is of critical importance as it uncovers the lesser examined underside of a two-sided coin. While the enabling upper side of the technological coin is celebrated, its disenabling, pathological underside is minimized or overlooked. This is the blindside accompanying the increasing technologization of society that is captured in the saying 'The fish is least able to describe the water it lives in!' This lack of awareness is commented on by Turkle in her insightful, cautionary accounts of the use of emerging technologies in contemporary society (Turkle 2011).

Combining insights as a clinical psychologist and an ethnographic researcher, Turkle addresses how the benefits of interactions on networks bring with them hidden personal and social costs too. Two quotes will serve to surface her concerns about the impact of new communicative technologies on personal, work, and social life:

It might seem intrusive, if not illegal, that my mobile phone would tell me the location of all my acquaintances within a ten-mile radius. But these days we are accustomed to all this. Life in a media bubble has come to seem natural. So has the end of a certain public etiquette: on the street, we speak into the invisible microphones on our mobile phones and appear to be talking to ourselves. We share intimacies with the air as though unconcerned about who can hear us or the details of our physical surroundings (Turkle 2011: 16).

Young people are among the first to grow up with an expectation of continuous connection: always on, and always on them. And they are among the first to grow up not necessarily thinking of simulation as second best. All this makes them fluent with technology but brings a set of new insecurities .... Their digitized friendships - played out with emoticon emotions, so often predicated on rapid response rather than reflection - may prepare them, at times through nothing more than their superficiality, for relationships that could bring superficiality to a higher power, that is, for relationships with the inanimate (Turkle 2011: 17).

It is for these reasons that as individuals and their societies increasingly embrace connective, enabling, and formative communications technologies, the question, 'What does technology do for me?' must also be accompanied by 
the other question, 'What does technology do to me?' Otherwise, under the illusion of human advancement, uncritical users will glorify in countless extensions and overextensions, while at the same time remaining ignorant of the severe amputations and erosions of critical facets of our humanity.

The Gospel cannot be reduced to a sound bite in a WhatsApp chat. The tradition of the Church should be made accessible, but cannot be made easy (Baron 2010). Many of the opportunities afforded by social networking are dreadfully self-referential, which is in sharp contrast to the Lord's missionary mandate that insists we not proclaim ourselves, but Christ the Lord. Also, there is a temptation to view the identity and relationships mediated by technology as more virtual than real, invented by human wilfulness, rather than grounded in truth and in love, a fact that we can see in the cruelty and coarseness that pervades so many Internet conversations. Therefore, let us use all these new media technologies to advance the mission of the Church, but let us not allow ourselves to be used by them.

\section{References}

Albergotti, R., D.R. MacMillan \& M. Evelyn 2014. Facebook's \$18 Billion Deal Sets High Bar. The Wall Street Journal 20 February: A1, A6.

Baron, R. 2010. Turn to the Spiritual Masters to Overcome Internet Superficiality (9323) 'Priests Online' - A Register. Experts Forum, Part 7.

Berger, A.A. 1995. Essentials of Mass Communication Theory. London: SAGE Publications.

https://doi.org/10.4135/9781483345420

Brookehoven, C. 2011. WhatsApp Leaks Usernames, Telephone Numbers and Messages. Your Daily Mac 19 May. Archived from the original on 23 May 23.

(Accessed on 18 July 2011.)

Chowdhry, A. WhatsApp Hits 500 Million Users. Forbes. (Accessed on 14 May 2014.)

CITC warns Skype, Viber, and WhatsApp 2013. Saudi Gazette (Jeddah). 31 March.

Gordon, W.T. 2010. McLuhan: A Guide for the Perplexed. New York: Continuum.

Jackson, E. 2012. Why Selling WhatsApp To Facebook would be the Biggest 
Mistake of Jan Koum's and Brian Acton's Lives. Forbes 3 December. (Accessed 3 May 2013.)

Katz, E. 2001. Media Effects. In Smelser N.J. \& P.B. Baltes (eds.): International Encyclopedia of the Social \& Behavioral Sciences. Oxford: Elsevier.

Koum, J. 2013. 400 Million Stories. WhatsApp Blog. WhatsApp 19 December (Accessed on 17 January 2014.)

Kurtz, A. 2011. Shooting the Messenger. 8 September. (Accessed on 11 September 2011).

Lasswell, H.D. 1970. Propaganda Technique in World War I. Cambridge: The M.I.T. Press.

Malekhosseini, R. 2018. Evaluation of Users' Privacy Concerns by Checking of their WhatsApp Status. Software-Practice \& Experience 48,5: 1143 1164.

https://doi.org/10.1002/spe.2565

McCarty, B. 2011. Signup Goof Leaves WhatsApp Users Open to Account Hijacking. The Next Web. McGraw-Hill. (Accessed 29 January 2013.)

McLuhan, M. 1965. Understanding Media: The Extensions of Man. New York. Pazmiño, R.W. 2008. Foundational Issues in Christian Education: An Introduction in Evangelical Perspective. Grand Rapids, MI: Baker Academic.

Privacy, Commissioner of Canada 2013. Investigation into the Personal Information Handling Practices of WhatsApp Inc. 2013._Findings Under the Personal Information Protection and Electronic Documents Act (PIPEDA). Report of Findings. 15 January 2013. (Accessed on 29 January 2013.)

Turkle, S. 2011. Alone Together: Why We Expect More from Technology and Less from Each Other. New York: Basic Books.

WhatsApp 2016. B2B Survey - External Customer and Supplier Communications. Survey of WhatsApp Users, February 2016.

Dr. Josephat Mutangadura Language, Media, and Visual Communication Tshwane University of Technology Pretoria josemuta@gmail.com mutangaduraj@tut.ac.za 
Josephat Mutangadura \& Itai Offat Manyanhaire

Itai Offat Manyanhaire Geography and Environmental Studies Faculty of Science Zimbabwe Open University offatmanyanhaire@gmail.com offatmanya@yahoo.com;manyanhaireo@zou.ac.zw 